Research

\title{
Sfrp5 mediates glucose-induced proliferation in rat pancreatic $\beta$-cells
}

\author{
Binbin Guan',2,*, Wenyi Li1,*, Fengying Li', Yun Xie', Qicheng Ni', Yanyun Gu', \\ Xiaoying Li', Qidi Wang', Hongli Zhang' ${ }^{1}$ and Guang Ning'
}

1Shanghai Institute of Endocrine and Metabolic Diseases, Shanghai Clinical Center for Endocrine and Metabolic Diseases, Department of Endocrinology and Metabolic Diseases, Ruijin Hospital, Shanghai Jiaotong University School of Medicine, Shanghai, P R China

2Department of Endocrinology, FuJian Union hospital, Fuzhou, P R China

*(B Guan and W Li contributed equally to this work)

Correspondence should be addressed to H Zhang

Email

hongliting@sina.com

\begin{abstract}
The cellular and molecular mechanisms of glucose-stimulated $\beta$-cell proliferation are poorly understood. Recently, secreted frizzled-related protein 5 (encoded by Sfrp5; a Wnt signaling inhibitor) has been demonstrated to be involved in $\beta$-cell proliferation in obesity. A previous study demonstrated that glucose enhanced Wnt signaling to promote cell proliferation. We hypothesized that inhibition of SFRP5 contributes to glucose-stimulated $\beta$-cell proliferation. In this study, we found that the Sfrp 5 level was significantly reduced in high glucose-treated INS-1 cells, primary rat $\beta$-cells, and islets isolated from glucose-infused rats. Overexpression of SFRP5 diminished glucosestimulated proliferation in both INS-1 cells and primary $\beta$-cells, with a concomitant inhibition of the Wnt signaling pathway and decreased cyclin D2 expression. In addition, we showed that glucose-induced Sfrp5 suppression was modulated by the PI3K/AKT pathway. Therefore, we conclude that glucose inhibits Sfrp 5 expression via the PI3K/AKT pathway and hence promotes rat pancreatic $\beta$-cell proliferation.
\end{abstract}

\author{
Key Words \\ - Sfrp5 \\ - glucose \\ - $\beta$-cell \\ - proliferation
}

\section{Introduction}

The $\beta$-cell mass is dynamic and can change rapidly on insulin demand during insulin resistance to maintain normoglycemia (Finegood et al. 1995, Bonner-Weir 2000, Accili 2001). Reductions in the $\beta$-cell mass are associated with type 2 diabetes in humans (Butler et al. 2003). The $\beta$-cell mass is regulated by a complicated balance of cell proliferation, neogenesis, apoptosis, and hypertrophy (Rhodes 2005). The proliferation of $\beta$-cells is considered to be a major component in maintaining the $\beta$-cell mass (Dor et al. 2004, Teta et al. 2007). However, the identity of the factors that control the $\beta$-cell mass remain elusive. Elucidating the factors and mechanisms responsible for pancreatic $\beta$-cell mass maintenance is crucial for the development of specific drug treatments for type 2 diabetes.

Several mitogens have been implicated in $\beta$-cell proliferation, including glucose, insulin-like growth factor 1 (IGF1), placental lactogens (PL), prolactin (PRL), glucagon-like peptide 1 (GLP1), hepatic growth factor (HGF), and parathyroid hormone-related protein (PTHrp) (Chick 1973, Brelje et al. 1993, Hugl et al. 1998, Buteau et al. 2003, Cozar-Castellano et al. 2006, Vasavada et al. 2007). Glucose is a potent $\beta$-cell mitogen that increases $\beta$-cell proliferation both in vitro and in vivo (Chick 1973). In vitro, glucose stimulates the proliferation of several rodent insulinoma cell lines and primary rodent islets

Published by Bioscientifica Ltd 
(Assmann et al. 2009, Metukuri et al. 2012, Zhang et al. 2012). In rat and mouse models, glucose infusion in vivo also results in an approximately 50\% increase in $\beta$-cell proliferation (Bonner-Weir et al. 1989, Alonso et al. 2007, Zhang et al. 2012). Glucose has been proposed to upregulate the expression of insulin receptor substrate 2 (IRS2) through increased cytosolic calcium levels and then activate the PI3K/AKT pathway to induce $\beta$-cell proliferation (Jhala et al. 2003, Heit et al. 2006, Porat et al. 2011). Other studies also reported the glucose-induced expression of cell-cycle regulators, including cyclin D2, and CDK4, and increased ChREBP transcriptional activity (Metukuri et al. 2012). Despite these observations, the mechanism mediating the mitogenic effect of glucose on $\beta$-cells is not fully understood.

Secreted frizzled-related protein 5 (SFRP5) is a member of the secreted frizzled-related protein family. SFRP5 sequesters WNT proteins in the extracellular space and prevents them from binding to their receptors, thereby inhibiting the activity of the Wnt signaling pathway (Kawano \& Kypta 2003). SFRP5 was one of the most extensively studied proteins in adipose tissue (Ouchi et al. 2010, Mori et al. 2012). Recently, Sfrp5 has been reported to be downregulated in the pancreatic islets of cafeteria diet-fed rats and involved in $\beta$-cell proliferation during the expansion of the $\beta$-cell mass in obesity through the regulation of Wnt signaling activity (Rebuffat et al. 2013). In our previous study, we performed Affymetrix microarrays on islets from a glucose-induced $\beta$-cell proliferation rat model, establishing by intravenous infusion of $50 \%$ glucose into rat. We observed a $64 \%$ decrease in Sfrp5 expression in the islets from glucose-infused rats (Supplementary Fig. 1, see section on supplementary data given at the end of this article). The downregulation of Sfrp5 activates Wnt signaling, which has been suggested to be a possible modulator of $\beta$-cell proliferation (Rulifson et al. 2007, Chocarro-Calvo et al. 2013). A previous study demonstrated that glucose enhanced Wnt signaling to promote cancer cell proliferation (Mao et al. 2013). In this study, we sought to clarify whether Sfrp5 was involved in the adaptive $\beta$-cell expansion induced by glucose through the inhibition of the Wnt signaling pathway.

In the current study, we found that Sfrp5 levels were significantly reduced in high glucose-treated INS-1 cells, primary rat islets, and islets isolated from rats infused with glucose for $24 \mathrm{~h}$. Overexpression of SFRP5 diminished glucose-stimulated proliferation in both INS-1 cells and primary $\beta$-cells, and was correlated with the inhibition of the Wnt signaling pathway. Moreover, glucose-induced Sfrp5 suppression was modulated by the PI3K/AKT pathway. We concluded that glucose reduced the Sfpr5 expression level via PI3K/Akt signaling and activated Wnt signaling to promote $\beta$-cell proliferation. This result could represent one of the intracellular mechanisms underlying glucose-stimulated $\beta$-cell proliferation.

\section{Materials and methods}

\section{Glucose infusion animal model}

Male Sprague-Dawley rats (approximately 8 weeks of age, 200-250g) were obtained from the Shanghai Experimental Animal Center, Chinese Academy of Sciences. The infusion into the animals was performed as described previously (Bonner-Weir et al. 1989). Briefly, adult male Sprague-Dawley rats were catheterized in the jugular vein by surgery. After a 3 to 5 -day recovery period, the rats received infusions of $0.45 \%$ saline $(n=10)$ or $50 \%$ glucose $(n=10)$ with $500 \mu \mathrm{g} / \mathrm{mL}$ bromodeoxyuridine (Sigma-Aldrich) at a constant rate of $2 \mathrm{~mL} / \mathrm{h}$ for $24 \mathrm{~h}$. The animals were allowed free access to regular chow and water during the infusion period. Blood samples were drawn from the tail veins. Blood glucose concentrations were measured using a portable blood glucose meter (Accu-Chek, Roche). After $24 \mathrm{~h}$ of infusion, a group of the infused animals was killed to isolate the islets. The remaining animals were killed for histological analyses. All procedures were performed in accordance with the principles of the Guide for the Care and Use of Experimental Animals of Shanghai Jiaotong University School of Medicine and were approved by the Animal Care Committee at Shanghai Jiaotong University.

\section{Islet purification and culture}

The islets were isolated from male Sprague-Dawley rats by common ductal collagenase infusion and separated by density gradient centrifugation (Zhang et al. 2012). Freshly isolated rat islets were transferred to a $6 \mathrm{~cm}$ dish and cultured overnight in DMEM containing $5.6 \mathrm{mM}$ glucose, $10 \mathrm{mM}$ HEPES, 10\% FBS, $100 \mathrm{IU} / \mathrm{mL}$ penicillin, and $100 \mu \mathrm{g} / \mathrm{mL}$ streptomycin at $37^{\circ} \mathrm{C}$ in a humidified $5 \%$ $\mathrm{CO}_{2}$ atmosphere before the next experiment.

\section{Cell culture}

INS-1 cells (passage 23-35) purchased from the CAMS Cell Culture Center (Beijing, China) were grown in RPMI 1640 medium containing $11.1 \mathrm{~m}$ glucose and supplemented with $10 \mathrm{mM}$ HEPES, $10 \%$ FBS, $2 \mathrm{mM}$ L-glutamine, $1 \mathrm{mM}$ sodium

Published by Bioscientifica Ltd 
pyruvate, $5 \mu \mathrm{l} / \mathrm{L} \beta$-mercaptoethanol, $100 \mathrm{IU} / \mathrm{mL}$ penicillin, and $100 \mu \mathrm{g} / \mathrm{mL}$ streptomycin at $37^{\circ} \mathrm{C}$ in a humidified $5 \%$ $\mathrm{CO}_{2}$ atmosphere. The cells were subcultured when they reached $80 \%$ confluence.

\section{Adenovirus infection and plasmid transfection}

The Sfrp5 adenovirus was a gift from Dr Jiqiu Wang (Shanghai Jiaotong University). The control green fluorescent protein (GFP) adenovirus was purchased from Boshang Biotech Company (Shanghai, China). INS-1 cells were plated in 6-well plates 1 day before infection. When the cell reached $70-80 \%$ confluence, each well was infected with adenovirus at an MOI of 20. For isolated rat islets, adenovirus was added at an MOI of 500 . PcDNA3.1-caAkt plasmid transfections were conducted using Lipofectamine 2000 (Invitrogen) according to the manufacturer's instructions.

\section{Proliferation assay}

For INS-1 cells, proliferation was assessed by 5-ethynyl-2'deoxyuridine (EdU) incorporation using the Click-iT EdU Flow Cytometry Assay Kit (Invitrogen). INS-1 cells were plated in a 6-well plate at a density of $3 \times 10^{5}$ cells/well in the growth medium. The next day, the cells were synchronized overnight with $2.8 \mathrm{mmol} / \mathrm{L}$ glucose and $0.2 \%$ BSA. For EdU incorporation, the cells were subsequently stimulated for $24 \mathrm{~h}$ in medium supplemented with various concentrations of glucose and $0.2 \%$ BSA. The EdU solution was added to the medium during the final $4 \mathrm{~h}$ of the $24 \mathrm{~h}$ incubation period. Detection of EdU incorporation was determined by flow cytometry using a BD FACSCalibur flow cytometer (Becton Dickinson Biosciences).

For isolated rat islets, the proliferation ratio was measured by the Click-iT EdU Image Assay Kit (Invitrogen). Isolated rat islets were dispersed with $0.25 \%$ trypsin/EDTA (Gibco) and plated on coverslips treated with polyl-lysine. Then, the dispersed rat islet cells were cultured for $24 \mathrm{~h}$ in media with $5.6 \mathrm{mmol} / \mathrm{L}$ glucose supplemented with $10 \%$ FBS. Next, steps were performed similar to those described for the INS-1 cells except that EdU was added for the last $24 \mathrm{~h}$.

\section{Real-time PCR}

Total RNA was extracted from INS-1 cells and isolated islets using the TRIzol reagent (Invitrogen) according to the manufacturer's protocol. After quantification using a spectrophotometer, $2 \mu \mathrm{g}$ of total RNA were used for reverse transcription with Superscript III (Invitrogen) with random hexamer primers. Quantitative PCR amplification and detection were performed with the SYBR Premix Ex Taq Mixes (TaKaRa, Kyoto, Japan) on an ABI Prism 7000 Sequence Detection System (Applied Biosystems). The specific primers used for real-time PCR were as follows: Sfrp5 (forward: 5'-GCCCAG AAGAAGAAGAAGCTGC-3'; reverse: 5'-TCTTCTTGTCCCAGCGGTAGAC-3') and $\beta$-actin (forward: $5^{\prime}$-AGGC CCCTCTGAACCCTAAG-3'; reverse: 5'-GGAGCGCGTAA CCCTCATAG-3'). The expression levels were normalized to $\beta$-actin. The results were analyzed using the $2-\Delta \Delta^{\mathrm{Ct}}$ method.

\section{Western blot}

The concentrations of proteins in the islets and INS- 1 cell lysates were quantitated by BCA protein assay (Pierce). Nuclear and cytoplasmic lysates were prepared with the NE-PER Kit (Pierce) according to the manufacturer's instructions. Protein samples $(20 \mu \mathrm{g})$ were separated by electrophoresis with an 8\% SDS-PAGE gel and transferred onto a polyvinylidene fluoride membrane, followed by immunoblotting according to the protocol outlined by Cell Signaling Technology. The blotted membrane was developed with ECL Advance (Cell Signaling) and imaged with a LAS-4000 Super CCD Remote Control Science Imaging System (GE). The relative abundance was quantified by densitometry using Quantity One 4.6.2 software (Bio-Rad). The following antibodies were used: mouse anti-SFRP5 (1:500, Santa Cruz Biotech), mouse anti-cyclin D2 (1:700, Abcam), rabbit anti-pAKT(473) (1:1000, Cell Signaling), rabbit anti-AKT (1:1000, Cell Signaling), mouse anti-tubulin (1:20,000, Sigma-Aldrich), and mouse anti-actin (1:1000, Santa Cruz).

\section{Immunocytofluorescence staining and $\beta$-cell replication analysis}

The pancreas were fixed in $4 \%$ paraformaldehyde at $4{ }^{\circ} \mathrm{C}$ overnight. The tissues were dehydrated, embedded in paraffin, and sectioned at $5 \mu \mathrm{m}$ thickness. The primary antibodies used were as follows: rabbit anti-BrdU (1:50, Sigma-Aldrich), guinea pig anti-insulin (1:800, Dako), mouse anti-SFRP5 (1:50, Santa Cruz Biotech), and rabbit anti-glucagon (1:100, Santa Cruz Biotech). Incubations were performed overnight in a humidified chamber at $4^{\circ} \mathrm{C}$. For BrdU/insulin staining, sections were treated with $1 \mathrm{M} \mathrm{HCl}$ at $37^{\circ} \mathrm{C}$ for $60 \mathrm{~min}$ before incubation

Published by Bioscientifica Ltd 
A

BrdU/Insulin/Dapi

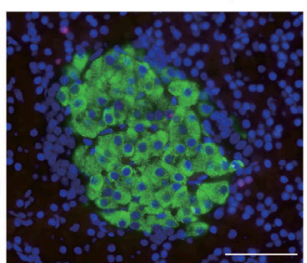

Saline

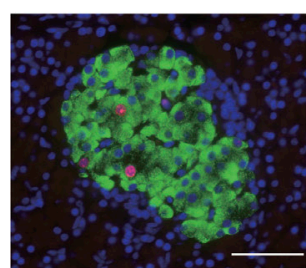

Glucose
B

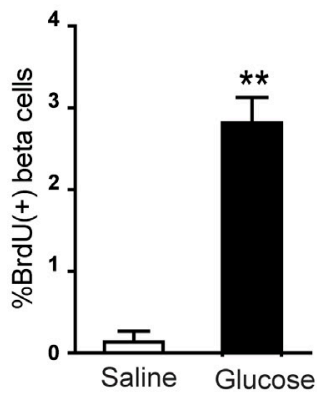

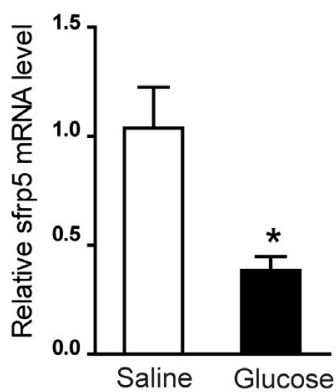
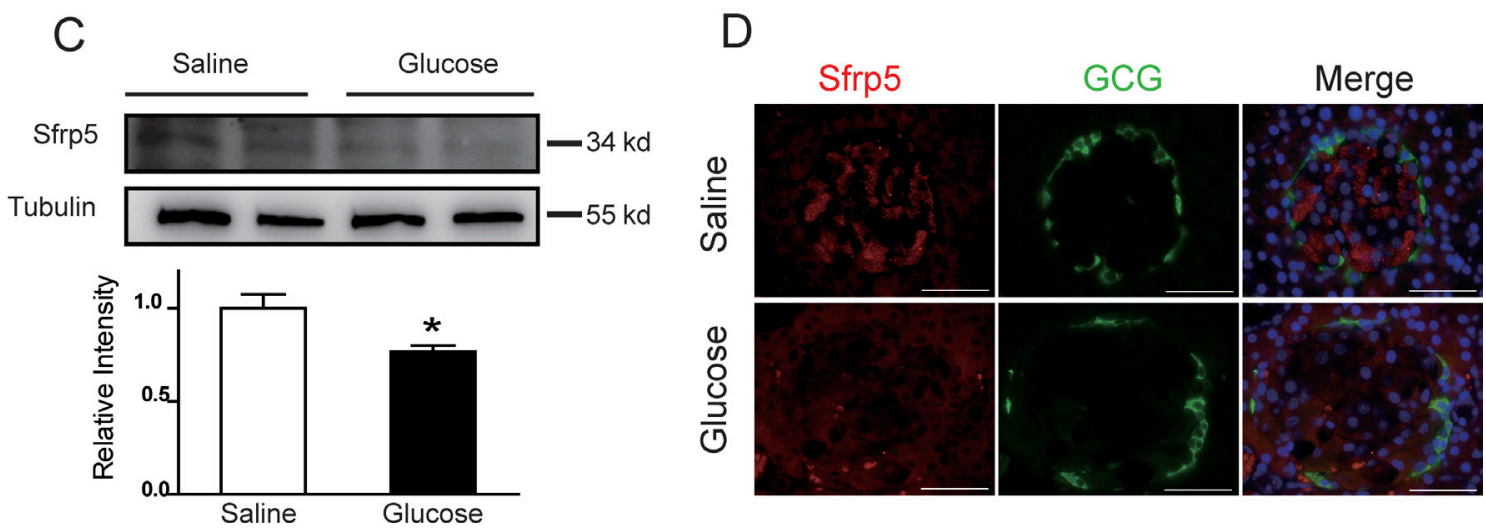

\section{Figure 1}

Glucose increases $\beta$-cell proliferation and reduces Sfrp5 expression in islets of glucose-infused rats (A) Immunofluorescence staining and analysis of BrdU (red) in pancreatic sections from rats infused with either saline or $50 \%$ glucose for $24 \mathrm{~h}$ ( $n=3$ rats per group). The percentage of BrdU and insulin double-staining cells were calculated. (B) Quantitative PCR analysis of Sfrp 5 mRNA levels in islets from rats infused with either saline or glucose for $24 \mathrm{~h}$ ( $n=4-5$ rats per group). (C) Western blot detection of SFRP5 protein levels in islets from rats infused with either saline or glucose for 24 h. SFRP5 band intensities were normalized based on the corresponding tubulin intensity ( $n=3$ rats per group). (D) Immunofluorescence staining for SFRP5 (red) and GCG (green) in pancreatic sections from rats infused with either saline or glucose for $24 \mathrm{~h}$. Data are presented as means \pm S.E.M. of independent experiments as indicated above, $* p<0.05, * * p<0.01$ for differences between the two groups.

with the primary antibody. Secondary antibodies were used as follows: Alexa Fluor 488 donkey anti-guinea pig (1:500, Jackson Immunoresearch), Alexa Fluor 488 donkey anti-rabbit (1:500, Jackson Immunoresearch), and Alexa Fluor 594 donkey anti-mouse (1:500, Life Technologies). Images were captured using an Olympus Microscope system.

After immunelabeling with BrdU and insulin, pancreatic islets in paraffin-embedded sections were photographed at $\times 400$ and assigned blinded filenames. The number of BrdU (+) $\beta$-cells was manually counted. At least $2000 \beta$-cells were counted per animal using three sections that were separated by at least $100 \mu \mathrm{m}$. Three animals per group were analyzed.

\section{Luciferase assays}

INS-1 cells infected with Sfrp5 adenovirus or GFP adenovirus were plated in 24-well plates $24 \mathrm{~h}$ before transfection. When the cells reached $70-80 \%$ confluence, they were transfected with plasmids (TopFlash and pRL-SV40) using Lipofectamine 2000 transfection reagent (Invitrogen). Six hours after transfection, the medium was changed to a medium supplemented with various concentrations of glucose and $0.2 \%$ BSA. Twenty-four hours later, the cells were lysed in 1XPLB, and luciferase assays were performed using the Dual-Luciferase Reporter Assay System (Promega) as recommended by the manufacturer. All luciferase assay experiments were performed in triplicate.

\section{Statistical analysis}

Comparisons were made using ANOVA for multiple groups or Student's t-test for two groups. Data are presented as the means \pm S.E.M. A value of $P<0.05$ was considered to be significant. Significance is indicated in the figures. 
A

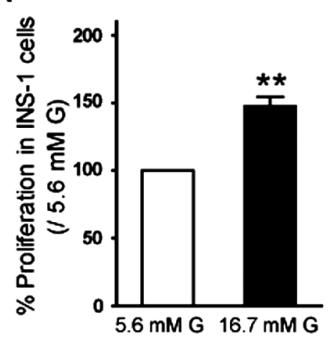

D

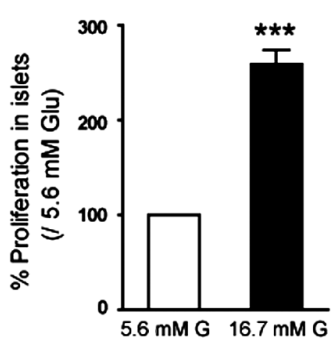

B

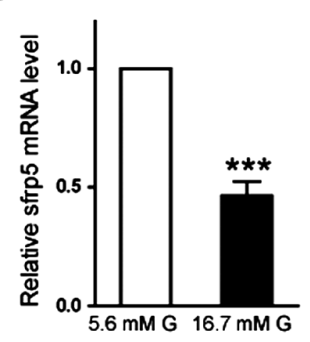

E

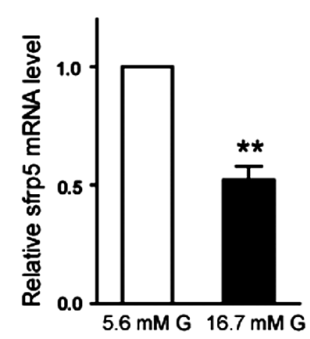

C

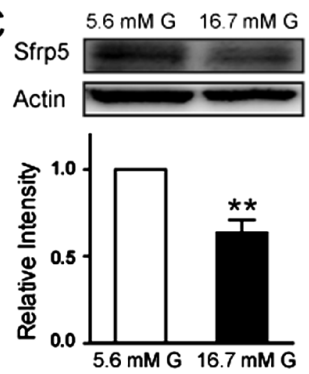

F

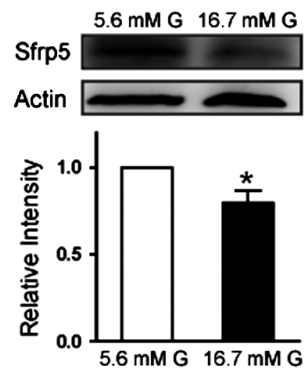

Figure 2

Glucose induces $\beta$-cell proliferation and inhibits Sfrp5 expression in vitro $A, D$ : INS-1 cells (A) and primary isolated islets (D) were incubated for $24 \mathrm{~h}$ with RPMI 1640 medium containing $0.2 \%$ BSA and 5.6 or $16.7 \mathrm{mM}$ glucose and then assessed for proliferation by EdU incorporation. $B, E$ : Quantitative PCR assay of Sfrp5 mRNA levels in INS-1 cells (B) and primary isolated islets (E) incubated with 5.6 or $16.7 \mathrm{mM}$ glucose for $24 \mathrm{~h} \mathrm{C}, F$ : Western blot detection of SFPR5 levels in INS-1 cells (C) and primary isolated islets (F) incubated with 5.6 or $16.7 \mathrm{mM}$ glucose for $24 \mathrm{~h}$. Representative immunoblot pictures are shown, and band intensities of SFRP5 are normalized based on the corresponding actin intensity. Data are presented as means \pm S.E.M. from at least triplicate independent experiments. $* P<0.05$, $* * P<0.01, * * * P<0.001$ for differences between the two groups.

\section{Results}

\section{Glucose infusion increases $\beta$-cell proliferation and reduces $S f r p 5$ expression in islets from glucose-infused rats}

We and others have reported that short-term continuous glucose infusion via the jugular vein promotes $\beta$-cell replication in rodents (Bonner-Weir et al. 1989, Alonso et al. 2007, Zhang et al. 2012). To clarify the underlying mechanisms of glucose-induced $\beta$-cell proliferation, we previously performed a clustering analysis of Affymetrix arrays on islets isolated from rats infused with 50\% glucose $(2 \mathrm{~mL} / \mathrm{h})$ or saline. The results revealed that the Sfrp 5 mRNA level decreased by $64 \%$ in the islets following 24 and $48 \mathrm{~h}$ of glucose infusion compared with saline (Supplementary Fig. 1). To confirm the correlation between Sfpr 5 and glucose-induced $\beta$-cell proliferation in vivo, we performed the experiments in a $24 \mathrm{~h}$ glucoseinfusion model. Infusion with 50\% glucose for $24 \mathrm{~h}$ caused a significant increase in plasma glucose and insulin levels in rats (Supplementary Fig. 2A and B). The pancreatic sections from these rats exhibited more BrdUpositive proliferative cells in the islets compared with the saline-infused rats (Fig. 1A). A quantification of BrdU/ insulin-positive cells revealed a robust and significant increase in $\beta$-cell replication in rats that received 50\% glucose $(2.8 \%)$ compared with rats that received saline (0.13\%) (Fig. 1A). Consistent with our microarray results, islets isolated from $24 \mathrm{~h}$ glucose-infused rats showed significant decreases in Sfrp5 mRNA expression and protein abundance compared with the saline-infused controls (Fig. 1B and C). The downregulation of SFRP5 in the glucose-infusion rat islets was confirmed by immunohistochemistry staining (Fig. 1D).

\section{Glucose induces islet $\beta$-cell proliferation and inhibits Sfrp5 expression in vitro}

In line with our in vivo observations, exposure of INS-1 cells and isolated islets to $16.7 \mathrm{mM}$ glucose for $24 \mathrm{~h}$ significantly increased the cell proliferation rates, which were approximately 1.5 - and 2.5-fold higher than those of cells exposed to basal glucose concentrations $(5.6 \mathrm{mM})$, respectively (Fig. 2A and D), as determined by EdU incorporation. Furthermore, there were significant decreases in Sfrp5 mRNA and protein abundance in INS-1 cells incubated with $16.7 \mathrm{mM}$ glucose compared with $5.6 \mathrm{mM}$ glucose (Fig. 2B and C). Similar results demonstrating the glucose-inhibited Sfrp 5 mRNA (Fig. 2E) and protein expression (Fig. 2F) were also observed in isolated rat islets, indicating that this phenomenon occurred in primary $\beta$-cells. These in vitro results demonstrated that glucose-induced $\beta$-cell proliferation was accompanied by a reduction in $S f r p 5$ expression.

\section{Overexpression of SFRP5 attenuates glucose-induced proliferation in INS-1 cells and primary islets}

Our present study demonstrated that high glucose stimulated $\beta$-cell proliferation, which was correlated with decreased $S$ frp 5 expression. $S f r p 5$ downregulation has been

Published by Bioscientifica Ltd. 

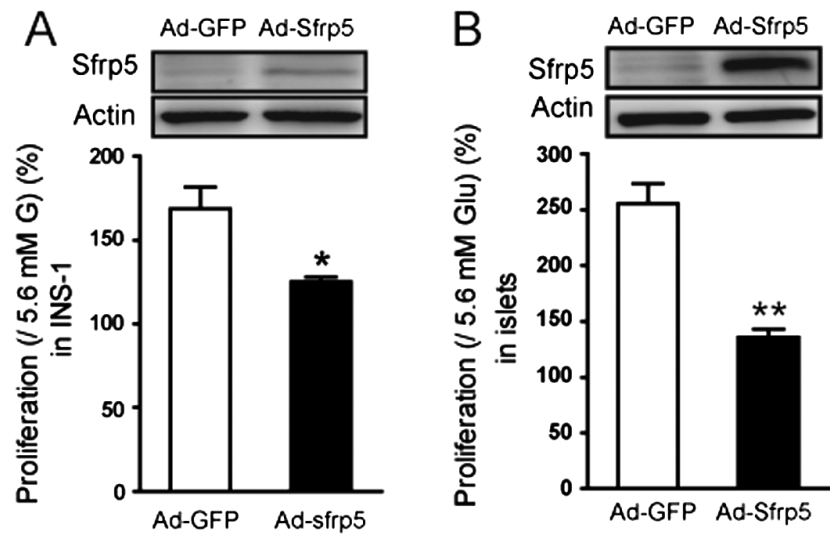

Figure 3

Overexpression of SFRP5 attenuates glucose-induced proliferation in INS1 cells and primary islets $A, B$ : Cell proliferation rates due to exposure to 5.6 or $16.7 \mathrm{mM}$ glucose were measured by the rate of EdU incorporation in INS-1 cells (A) and primary islets (B) after infection with Ad-GFP or Ad-Sfrp5. The upper portion of A, B shows representative immunoblot pictures of SFRP5 and actin in INS-1 cells and islets infected with the indicated adenoviruses for $48 \mathrm{~h}$. The results are presented as the means \pm S.E.M. from at least triplicate independent experiments. ${ }^{*} P<0.05$, $* * P<0.01$ for differences between the two groups.

shown to enhance the proliferation of pancreatic $\beta$-cells (Rebuffat et al. 2013). To elucidate the function of $S f r p 5$ in glucose-induced $\beta$-cell proliferation, we overexpressed SFRP5 in INS-1 cells and primary islets using an adenoviral vector. After $48 \mathrm{~h}$ of infection, the INS-1 cells and primary islets were subjected to the glucose-induced proliferation assay. As shown in Fig. 3A, the infection of INS-1 cells with Ad-Sfrp 5 increased the abundance of SFRP5 as determined by immunoblotting. Overexpression of SFRP5 abolished glucose-induced $\beta$-cell proliferation as determined by EdU incorporation compared with INS-1 cells treated with Ad-GFP (Fig. 3A) Similar observations were obtained in dispersed rat islets with SFRP5 overexpression (Fig. 3B). Meanwhile, overexpression of SFRP5 did not affect the EdU incorporation in INS-1 cells and dispersed rat islets at basal glucose concentration $(5.6 \mathrm{mM}$ ) (Supplementary Fig. 3A and B). These findings indicated that Sfrp5 may play a negative role in glucose-induced $\beta$-cell proliferation.

\section{Sfpr5 impairs glucose-induced Wnt signaling pathway activation and decreases cyclin D2 expression in INS-1 cells}

Sfrp5 is a negative regulator of Wnt signaling. A previous study demonstrated that the Wnt signaling pathway regulated $\beta$-cell proliferation (Rulifson et al. 2007), while glucose enhanced Wnt signaling to promote cancer cell proliferation (Chocarro-Calvo et al. 2013, Mao et al. 2013).
We examined whether Sfrp5 was involved in glucoseinduced $\beta$-cell expansion by inhibiting the Wnt signaling pathway. As shown in Fig. 4A, $16.7 \mathrm{mM}$ glucose increased the accumulation of $\beta$-catenin, the characteristic protein of the Wnt pathway, in the nucleus of INS-1 cells (Fig. 4 A). Overexpression of SFRP5 in INS-1 cells blocked this translocation under the high glucose condition (Fig. 4A). These data indicated that high glucose may activate Wnt signaling and increase subsequent cell proliferation via Sfrp5 inhibition. To further verify this possibility, we used a Wnt signaling reporter assay (TCF responsive luciferase reporter vector) to measure Wnt signaling in INS- 1 cells stimulated by high glucose. Indeed, high glucose promoted TCF luciferase gene reporter activity, and overexpression of SFRP5 impaired the glucose-mediated activity (Fig. 4B). Additionally, we analyzed the expression of cyclin D2, a cell cycle regulator regulated by Wnt signaling in $\beta$-cells (Kushner et al. 2005, Rulifson et al. 2007, Chen et al. 2012). We found that overexpression of SFRP5 muted glucose-dependent cyclin D2 expression (Fig. 4C). These findings suggested that Sfrp 5 diminished glucosestimulated proliferation in $\beta$-cells through the inhibition of the Wnt signaling pathway and the subsequent cyclin D2 expression.

\section{Sfrp5 expression is modulated by glucose through the PI3K/AKT pathway}

The PI3K/AKT pathway is known to be an important intracellular signaling cascade for glucose-stimulated pancreatic $\beta$-cell proliferation (Weir \& Bonner-Weir 2007, Assmann et al. 2009). We postulated that the regulation of $S$ frp 5 by glucose in $\beta$-cells may also be mediated by the PI3K/AKT pathway. We used a PI3K inhibitor (Ly294002) to inhibit endogenous PI3K activity in INS-1 cells. As expected, LY294002 reduced AKT phosphorylation and reversed glucose-induced Sfrp5 repression at both the mRNA and protein levels (Fig. $5 \mathrm{~A}$ and $\mathrm{B}$ ). To further confirm our hypothesis, we transfected INS-1 cells with constitutively active AKT (caAKT) and found that these caAkt-transfected cells showed significantly decreased Sfrp5 expression levels compared with cells transfected with the control vectors (Fig. 5C and D). We concluded that glucose decreased Sfrp5 expression in a PI3K/AKTdependent manner in $\beta$-cells.

\section{Discussion}

The proliferation of $\beta$-cells is an important mechanism in the maintenance of the functional $\beta$-cell mass in response

Published by Bioscientifica Ltd 
A
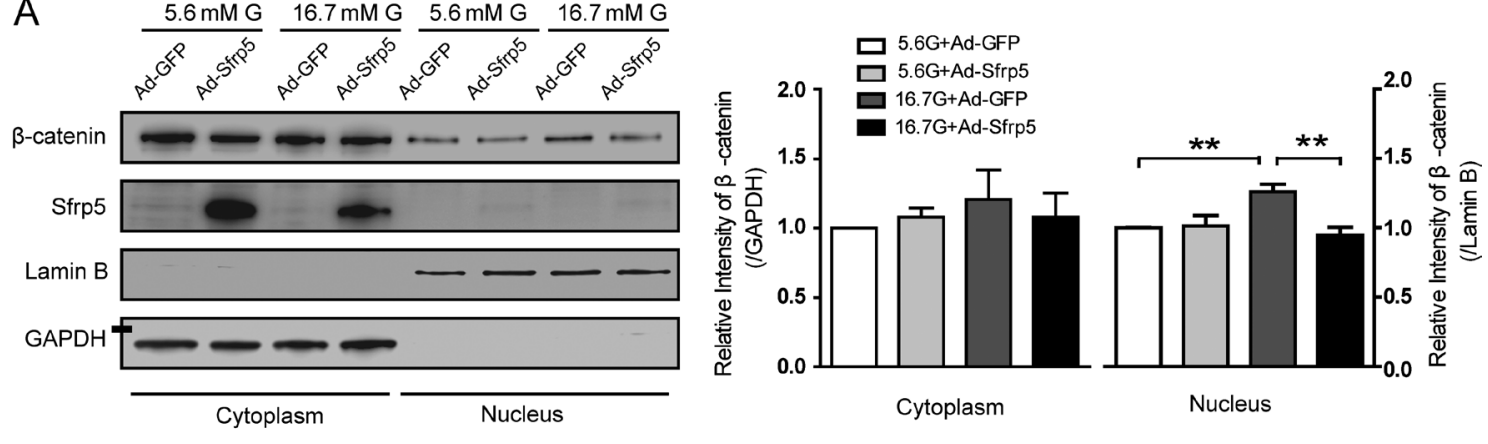

B

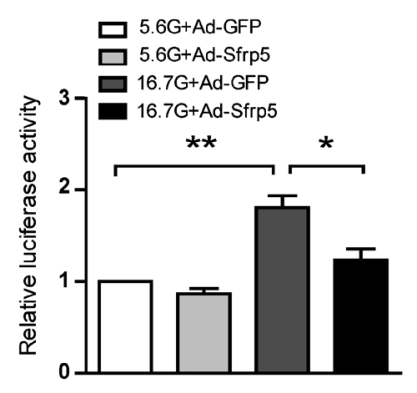

C

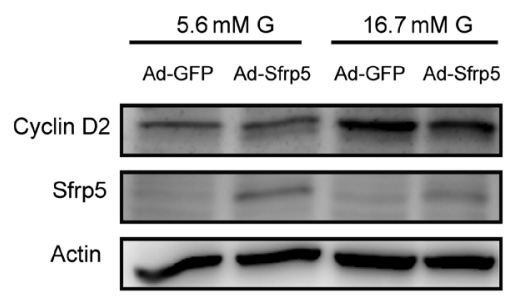

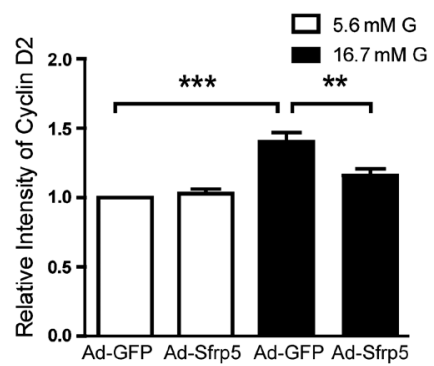

\section{Figure 4}

SFPR5 impairs glucose-induced activation of the canonical Wnt signaling pathway and decreases cyclin D2 expression in INS1 cells. (A) Western blot detection of $\beta$-catenin level in the cytoplasm and nucleus of INS-1 cells treated with 5.6 or $16.7 \mathrm{mM}$ glucose after infection with Ad-Sfrp5 or Ad-GFP. Representative immunoblot pictures are shown, and band intensities of SFRP5 were normalized based on the corresponding GAPDH intensity. (B) Overexpression of SFRP5 decreased TCF luciferase gene reporter activity activated by glucose in INS-1 cells. (C) Western blot detection of cyclin D2 levels in cells treated with 5.6 or $16.7 \mathrm{mM}$ glucose after infection with Ad-Sfrp5 or Ad-GFP. Representative immunoblot pictures are shown, and band intensities of cyclin D2 were normalized based on the corresponding actin intensity. Data are presented as the means \pm S.E.M. from at least triplicate independent experiments. ${ }^{*} P<0.05, * * P<0.01, * * * P<0.001$ for differences between the two groups.

to various metabolic demands (Dor et al. 2004, Ogino et al. 2006, Gupta et al. 2007, Okada et al. 2007, Teta et al. 2007). The failure to increase $\beta$-cell proliferation may result in glucose intolerance and eventually lead to diabetes mellitus (Butler et al. 2003, Prentki \& Nolan 2006). Thus, understanding how $\beta$-cells proliferate and elucidating the molecular mechanisms that natural mitogens stimulate the expansion of functional $\beta$-cells is beneficial for diabetes therapy. Glucose is a well-known potent $\beta$-cell mitogen in mice, rats, and humans, and plays a dominant role in the $\beta$-cell compensation of insulin demands (Chick 1973, Bonner-Weir et al. 1989, Alonso et al. 2007, Terauchi et al. 2007, Weir \& Bonner-Weir 2007, Levitt et al. 2011). However, the mechanisms underlying its mitogenic activity remain unclear. Our study demonstrated that glucose-stimulated $\beta$-cell proliferation may at least in part be mediated by $S$ frp 5 regulation. We found that glucoseinduced islet $\beta$-cell proliferation correlated with reduced Sfrp5 expression both in vitro and in vivo. Overexpression of SFRP5 inhibited glucose-induced proliferation through the inactivation of the Wnt pathway.

SFRP5 is a member of the SFRP protein family and contains a cysteine-rich domain homologous to the putative Wnt-binding site of the frizzled proteins, which act as negative modulators of Wnt signaling (Kawano \& Kypta 2003). Previous studies on Sfrp 5 mainly focused on adipogenesis and development of obesity but produced contradictory results. Ouchi et al. (2010) reported that SFRP5 secretion by adipocytes exerted salutary effects on metabolic dysfunction by controlling inflammatory cells within the adipose tissue. Sfrp5-deficient mice exhibited severe glucose intolerance upon consumption of a high fat-high sugar diet. However, in a different study, Sfrp5-deficient mice were reported to exhibit mild improvements in glucose tolerance upon consumption of a high-fat diet (Mori et al. 2012). Studies investigating the function of Sfrp5 in $\beta$-cells are limited. Recently, Sfrp5 was demonstrated to regulate $\beta$-cell proliferation in obese rats (Rebuffat et al. 2013) and may also play a role in the regulation of pancreatic $\beta$-cell function (Rulifson et al. 2014). Rebuffat et al. (2013) found the Sfrp5 was downregulated in the islets of cafeteria dietfed rats. In turn, this downregulation promoted $\beta$-cell proliferation by activating the Wnt signaling pathway. In our study, we found that glucose decreased Sfrp5 expression in high glucose-treated INS-1 cells, primary

Published by Bioscientifica Ltd 
A

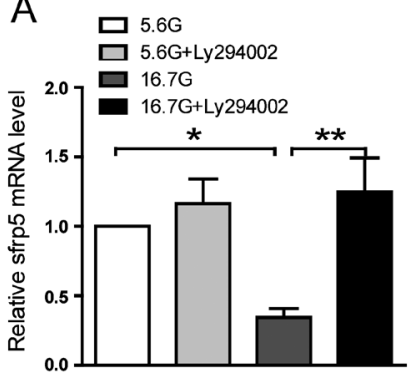

$\mathrm{C}$

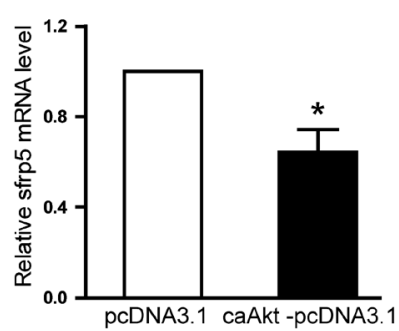

B
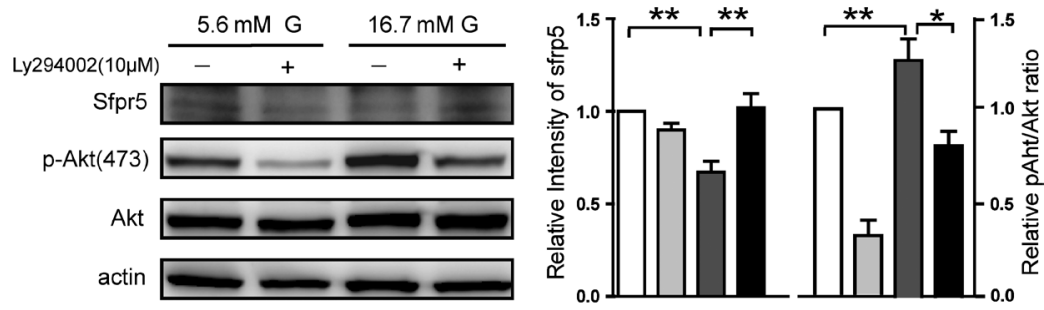

$\mathrm{D}$

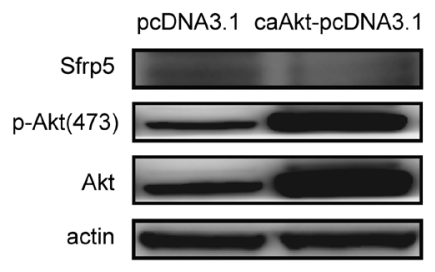

\section{Figure 5}

Sfrp5 expression is modulated by glucose through the PI3K/Akt pathway (A) Quantitative PCR analysis of Sfrp5 mRNA levels in INS-1 cells exposed to $10 \mu \mathrm{M}$ Ly294002. (B) Western blot detection of SFRP5, pAkt(473) protein levels in INS-1 cells exposed to $10 \mu \mathrm{M}$ Ly294002. Band intensities of SFRP5 were normalized based on the corresponding actin intensity, pAkt(473) were normalized to total Akt. (C) Quantitative PCR analysis of Sfrp5 mRNA levels in INS-1 cells transfected with caAkt-pcDNA3.1 or the control vector. (D) Western blot detection of SFRP5, pAKT(473), and AKT protein levels in INS-1 cells transfected with caAkt-pcDNA3.1 or the control vector. Band intensities of SFRP5 were normalized based on the corresponding actin intensity. Data are presented as the means \pm S.E.M. from at least triplicate independent experiments. $* P<0.05, * * P<0.01$ for differences between the two groups.

isolated islets, and islets isolated from glucose-infused rats. Our observation may also have clinical relevance because circulating SFRP5 levels were found to be decreased in humans with hyperglycemia ( $\mathrm{Hu}$ et al. 2013). Moreover, overexpression of SFRP5 diminished glucose-induced proliferation due to the inactivation of the Wnt pathway. These results demonstrated that Sfrp 5 was also involved in glucose-induced $\beta$-cell proliferation. Obesity and hyperglycemia are common physiological conditions with increased insulin demand that result in compensatory $\beta$-cell proliferation. Based on the findings from Rebuffat et al. (2013) and this study, we suggest that $S f r p 5$ is a critical component involved in compensatory $\beta$-cell proliferation. Whether Sfrp5 is involved in pancreatic $\beta$-cell proliferation in response to other physiological replication stimuli deserves further investigation.

Previous studies revealed that Wnt signaling controlled islet $\beta$-cell proliferation and that glucose could enhance Wnt signaling to promote cancer cell proliferation (Rulifson et al. 2007, Liu \& Habener 2008, Figeac et al. 2010, Chocarro-Calvo et al. 2013, Mao et al. 2013). However, whether glucose could activate Wnt signaling to promote cell growth in $\beta$-cells is unknown. In our study, we found that glucose allowed $\beta$-catenin translocation into the nucleus and promoted TCF luciferase reporter gene activity, indicating that the Wnt pathway was activated. Overexpression of SFRP5 not only inhibited the glucose-induced activation of the Wnt pathway but also impaired the glucose-stimulated proliferation of $\beta$-cells. These results demonstrated that glucose may promote $\beta$-cell proliferation, at least in part, through the activation of the Wnt pathway. Cyclin D2 is an essential cell cycle regulator that is controlled by Wnt signaling in pancreatic $\beta$-cells (Rulifson et al. 2007). Indeed, cyclin D2 was found to be upregulated in insulinoma cell lines treated with high glucose and islets from glucose-infused rats (Alonso et al. 2007, Rulifson et al. 2007, Salpeter et al. 2011). Our results demonstrated that cyclin D2 upregulation initiated by glucose could be attenuated by overexpression of the Wnt signaling inhibitor SFRP5. Our finding suggests a new mechanism for glucose-stimulated $\beta$-cell proliferation in which glucose inhibits Sfrp5 and thereby activates Wnt signaling to increase the level of cyclin D2.

In this study, we identified a novel mechanism through which glucose boosts $\beta$-cell proliferation by repressing $S f r p 5$ expression and subsequently leads to activation of the Wnt signaling pathway. However, the mechanism by which glucose regulates

Published by Bioscientifica Ltd. 
Sfrp5 expression is not understood. Glucose has been demonstrated to upregulate IRS2 expression, leading to the downstream activation of PI3K/AKT signaling (Lingohr et al. 2006), which plays a critical role in maintaining $\beta$-cell proliferation and survival (Kasuga 2006). Our findings showed that the inhibition of PI3K reversed glucose-induced Sfrp5 repression, whereas the sustained activation of AKT significantly decreased Sfrp5 expression. Our data indicated that glucose decreased Sfrp5 expression in a PI3K/AKTdependent manner in $\beta$-cells. In line with our findings, Rebuffat and coworkers recently demonstrated that Sfrp5 expression in $\beta$-cells was promoted by IGFBP3 (Rebuffat et al. 2013), which exerted anti-proliferative effects in other cell types by blocking IGF1-mediated PI3K/AKT (Buckbinder et al. 1995). However, further studies are required to establish the precise mechanisms by which transcriptional factors may be involved in the regulation. Furthermore, Wnt signaling could be modulated by the PI3K/AKT signaling pathway through the regulation of GSK3 $\beta$ phosphorylation and the direct inhibition of $\beta$-catenin nuclear localization (Fukumoto et al. 2001, Lee et al. 2010). Our results indicate another mechanism: in addition to phosphorylated GSK3 $\beta$, the PI3K/AKT pathway can activate the Wnt pathway by downregulating the expression of the Wnt pathway inhibitor SFRP5. Thus, it is plausible that Sfrp5 is another molecule that mediates the cross talk between the Wnt and PI3K/AKT signaling pathways.

In summary, our results demonstrated that the SFRP5/Wnt pathway was required for glucose-induced $\beta$-cell proliferation and was regulated by glucose via the PI3K/AKT signaling pathway. Our findings provide novel insights into the mechanism of compensatory $\beta$-cell proliferation in response to increased insulin demand. Therefore, Sfrp 5 may serve as a target to expand functional pancreatic islets in diabetic patients.

\section{Supplementary data}

This is linked to the online version of the paper at http://dx.doi.org/10.1530/ JOE-15-0535.

\section{Declaration of interest}

The authors declare that there is no conflict of interest that could be perceived as prejudicing the impartiality of the research reported.

\section{Funding}

This work was supported by the National Natural Science Foundation of China $(81270860,81200565,81370875)$

$$
\text { http://joe.endocrinology-journals.org }
$$$$
\text { DOI: } 10.1530 / J O E-15-0535
$$

(c) 2016 Society for Endocrinology Printed in Great Britain

\section{Author contributions}

$B$ G and $W L$ researched data, wrote the manuscript, and reviewed/ edited the manuscript; $F \mathrm{~L}, \mathrm{Y} X, \mathrm{Q} N$ and $\mathrm{Y} G$ researched data and contributed to discussion; $\mathrm{X} L$ and $\mathrm{Q} W$ contributed to discussion, edited the manuscript; $\mathrm{H} \mathrm{Z}$ conceived the project and designed the experiments, contributed to discussion, wrote the manuscript, and reviewed/edited the manuscript; N G contributed to discussion, and reviewed the manuscript.

\section{Acknowledgments}

The authors thank Dr Jiqiu Wang for presenting the Sfrp 5 adenovirus and suggesting for the research.

\section{References}

Accili D 2001 A kinase in the life of the beta cell. Journal of Clinical Investigation 108 1575-1576. (doi:10.1172/JCI14454)

Alonso LC, Yokoe T, Zhang P, Scott DK, Kim SK, O'Donnell CP \& Garcia-Ocana A 2007 Glucose infusion in mice: a new model to induce beta-cell replication. Diabetes 56 1792-1801. (doi:10.2337/db06-1513)

Assmann A, Ueki K, Winnay JN, Kadowaki T \& Kulkarni RN 2009 Glucose effects on beta-cell growth and survival require activation of insulin receptors and insulin receptor substrate 2. Molecular and Cellular Biology 29 3219-3228. (doi:10.1128/MCB.01489-08)

Bonner-Weir S 2000 Islet growth and development in the adult. Journal of Molecular Endocrinology 24 297-302. (doi:10.1677/ jme.0.0240297)

Bonner-Weir S, Deery D, Leahy JL \& Weir GC 1989 Compensatory growth of pancreatic beta-cells in adult rats after short-term glucose infusion. Diabetes 38 49-53. (doi:10.2337/diab.38.1.49)

Brelje TC, Scharp DW, Lacy PE, Ogren L, Talamantes F, Robertson M, Friesen HG \& Sorenson RL 1993 Effect of homologous placental lactogens, prolactins, and growth hormones on islet B-cell division and insulin secretion in rat, mouse, and human islets: implication for placental lactogen regulation of islet function during pregnancy. Endocrinology 132 879-887. (doi:10.1210/endo.132.2.8425500)

Buckbinder L, Talbott R, Velasco-Miguel S, Takenaka I, Faha B, Seizinger BR \& Kley N 1995 Induction of the growth inhibitor IGF-binding protein 3 by p53. Nature 377 646-649. (doi:10.1038/377646a0)

Buteau J, Foisy S, Joly E \& Prentki M 2003 Glucagon-like peptide 1 induces pancreatic beta-cell proliferation via transactivation of the epidermal growth factor receptor. Diabetes 52 124-132. (doi:10.2337/diabetes.52.1.124)

Butler AE, Janson J, Bonner-Weir S, Ritzel R, Rizza RA \& Butler PC 2003 Beta-cell deficit and increased beta-cell apoptosis in humans with type 2 diabetes. Diabetes 52 102-110. (doi:10.2337/ diabetes.52.1.102)

Chen S, Shimoda M, Chen J, Matsumoto S \& Grayburn PA 2012 Transient overexpression of cyclin D2/CDK4/GLP1 genes induces proliferation and differentiation of adult pancreatic progenitors and mediates islet regeneration. Cell Cycle 11 695-705. (doi:10.4161/cc.19928)

Chick WL 1973 Beta cell replication in rat pancreatic monolayer cultures. Effects of glucose, tolbutamide, glucocorticoid, growth hormone and glucagon. Diabetes 22 687-693. (doi:10.2337/ diab.22.9.687)

Chocarro-Calvo A, Garcia-Martinez JM, Ardila-Gonzalez S, De la Vieja A \& Garcia-Jimenez C 2013 Glucose-induced beta-catenin acetylation enhances Wnt signaling in cancer. Molecular Cell 49 474-486. (doi:10.1016/j.molcel.2012.11.022)

Published by Bioscientifica Ltd 
Cozar-Castellano I, Weinstock M, Haught M, Velazquez-Garcia S, Sipula D \& Stewart AF 2006 Evaluation of beta-cell replication in mice transgenic for hepatocyte growth factor and placental lactogen: comprehensive characterization of the G1/S regulatory proteins reveals unique involvement of p21cip. Diabetes 55 70-77. (doi:10.2337/diabetes.55.01.06.db05-0632)

Dor Y, Brown J, Martinez OI \& Melton DA 2004 Adult pancreatic beta-cells are formed by self-duplication rather than stem-cell differentiation. Nature 429 41-46. (doi:10.1038/ nature02520)

Figeac F, Uzan B, Faro M, Chelali N, Portha B \& Movassat J 2010 Neonatal growth and regeneration of beta-cells are regulated by the Wnt/betacatenin signaling in normal and diabetic rats. American Journal of Physiology: Endocrinology and Metabolism 298 E245-256. (doi:10.1152/ ajpendo.00538.2009)

Finegood DT, Scaglia L \& Bonner-Weir S 1995 Dynamics of beta-cell mass in the growing rat pancreas. Estimation with a simple mathematical model. Diabetes 44 249-256. (doi:10.2337/diab.44.3.249)

Fukumoto S, Hsieh CM, Maemura K, Layne MD, Yet SF, Lee KH, Matsui T, Rosenzweig A, Taylor WG, Rubin JS, et al. 2001 Akt participation in the Wnt signaling pathway through dishevelled. Journal of Biological Chemistry 276 17479-17483. (doi:10.1074/jbc.C000880200)

Gupta RK, Gao N, Gorski RK, White P, Hardy OT, Rafiq K, Brestelli JE, Chen G, Stoeckert CJ Jr \& Kaestner KH 2007 Expansion of adult beta-cell mass in response to increased metabolic demand is dependent on HNF-4alpha. Genes \& Development 21 756-769. (doi:10.1101/gad.1535507)

Heit JJ, Karnik SK \& Kim SK 2006 Intrinsic regulators of pancreatic betacell proliferation. Annual Review of Cell and Developmental Biology 22 311-338. (doi:10.1146/annurev.cellbio.22.010305.104425)

Hugl SR, White MF \& Rhodes CJ 1998 Insulin-like growth factor I (IGF-I)-stimulated pancreatic beta-cell growth is glucose-dependent. Synergistic activation of insulin receptor substrate-mediated signal transduction pathways by glucose and IGF-I in INS-1 cells. Journal of Biological Chemistry 273 17771-17779. (doi:10.1074/ jbc.273.28.17771)

Hu W, Li L, Yang M, Luo X, Ran W, Liu D, Xiong Z, Liu H \& Yang G 2013 Circulating Sfrp5 is a signature of obesity-related metabolic disorders and is regulated by glucose and liraglutide in humans. Journal of Clinical Endocrinology \& Metabolism 98 290-298. (doi:10.1210/jc.2012-2466)

Jhala US, Canettieri G, Screaton RA, Kulkarni RN, Krajewski S, Reed J, Walker J, Lin X, White M \& Montminy M 2003 cAMP promotes pancreatic beta-cell survival via CREB-mediated induction of IRS2. Genes \& Development 17 1575-1580. (doi:10.1101/gad.1097103)

Kasuga M 2006 Insulin resistance and pancreatic beta cell failure. Journal of Clinical Investigation 116 1756-1760. (doi:10.1172/ JCI29189)

Kawano Y \& Kypta R 2003 Secreted antagonists of the Wnt signalling pathway. Journal of Cell Science 116 2627-2634. (doi:10.1242/ jcs.00623)

Kushner JA, Ciemerych MA, Sicinska E, Wartschow LM, Teta M, Long SY, Sicinski P \& White MF 2005 Cyclins D2 and D1 are essential for postnatal pancreatic beta-cell growth. Molecular and Cellular Biology 25 3752-3762. (doi:10.1128/MCB.25.9.3752 3762.2005)

Lee G, Goretsky T, Managlia E, Dirisina R, Singh AP, Brown JB, May R, Yang GY, Ragheb JW, Evers BM, et al. 2010 Phosphoinositide 3-kinase signaling mediates beta-catenin activation in intestinal epithelial stem and progenitor cells in colitis. Gastroenterology 139 869-881, 881 e861-869. (doi:10.1053/j.gastro.2010.05.037)

Levitt HE, Cyphert TJ, Pascoe JL, Hollern DA, Abraham N, Lundell RJ, Rosa T, Romano LC, Zou B, O’Donnell CP, et al. 2011 Glucose stimulates human beta cell replication in vivo in islets transplanted into NOD-severe combined immunodeficiency (SCID) mice. Diabetologia 54 572-582. (doi:10.1007/s00125-010-1919-1)
Lingohr MK, Briaud I, Dickson LM, McCuaig JF, Alarcon C, Wicksteed BL \& Rhodes CJ 2006 Specific regulation of IRS-2 expression by glucose in rat primary pancreatic islet beta-cells. Journal of Biological Chemistry 281 15884-15892. (doi:10.1074/ jbc.M600356200)

Liu Z \& Habener JF 2008 Glucagon-like peptide-1 activation of TCF7L2-dependent Wnt signaling enhances pancreatic beta cell proliferation. Journal of Biological Chemistry 283 8723-8735. (doi:10.1074/jbc.m706105200)

Mao J, Hu X, Xiao Y, Yang C, Ding Y, Hou N, Wang J, Cheng H \& Zhang X 2013 Overnutrition stimulates intestinal epithelium proliferation through beta-catenin signaling in obese mice. Diabetes 62 3736-3746. (doi:10.2337/ db13-0035)

Metukuri MR, Zhang P, Basantani MK, Chin C, Stamateris RE, Alonso LC, Takane KK, Gramignoli R, Strom SC, O’Doherty RM et al. 2012 ChREBP mediates glucose-stimulated pancreatic beta-cell proliferation. Diabetes 61 2004-2015. (doi:10.2337/db11-0802)

Mori H, Prestwich TC, Reid MA, Longo KA, Gerin I, Cawthorn WP, Susulic VS, Krishnan V, Greenfield A \& Macdougald OA 2012 Secreted frizzled-related protein 5 suppresses adipocyte mitochondrial metabolism through WNT inhibition. Journal of Clinical Investigation 122 2405-2416. (doi:10.1172/JCI63604)

Ogino J, Sakurai K, Yoshiwara K, Suzuki Y, Ishizuka N, Seki N, Koseki H, Shirasawa T, Hashimoto N, Yagui K, et al. 2006 Insulin resistance and increased pancreatic beta-cell proliferation in mice expressing a mutant insulin receptor (P1195L). Journal of Endocrinology 190 739-747. (doi:10.1677/joe.1.06849)

Okada T, Liew CW, Hu J, Hinault C, Michael MD, Krtzfeldt J, Yin C, Holzenberger M, Stoffel M \& Kulkarni RN 2007 Insulin receptors in beta-cells are critical for islet compensatory growth response to insulin resistance. PNAS 104 8977-8982. (doi:10.1073/ pnas.0608703104)

Ouchi N, Higuchi A, Ohashi K, Oshima Y, Gokce N, Shibata R, Akasaki Y, Shimono A \& Walsh K 2010 Sfrp5 is an anti-inflammatory adipokine that modulates metabolic dysfunction in obesity. Science 329 454-457. (doi:10.1126/ science.1188280)

Porat S, Weinberg- N, Tornovsky-Babaey S, Schyr-Ben-Haroush R, Hija A, Stolovich-Rain M, Dadon D, Granot Z, Ben-Hur V, White P, et al. 2011 Control of pancreatic beta cell regeneration by glucose metabolism. Cell Metabolism 13 440-449. (doi:10.1016/j.cmet.2011.02.012)

Prentki M \& Nolan CJ 2006 Islet beta cell failure in type 2 diabetes. Journal of Clinical Investigation 116 1802-1812. (doi:10.1172/jci29103)

Rebuffat SA, Oliveira JM, Altirriba J, Palau N, Garcia A, Esteban Y, Nadal B \& Gomis R 2013 Downregulation of Sfrp5 promotes beta cell proliferation during obesity in the rat. Diabetologia $562446-2455$. (doi:10.1007/s00125-013-3030-x)

Rhodes CJ 2005 Type 2 diabetes-a matter of beta-cell life and death? Science 307 380-384. (doi:10.1126/science.1104345)

Rulifson IC, Karnik SK, Heiser PW, ten Berge D, Chen H, Gu X, Taketo MM, Nusse R, Hebrok M \& Kim SK 2007 Wnt signaling regulates pancreatic beta cell proliferation. PNAS 104 6247-6252. (doi:10.1073/pnas.0701509104)

Rulifson IC, Majeti JZ, Xiong Y, Hamburger A, Lee KJ, Miao L, Lu M, Gardner J, Gong Y, Wu H, et al. 2014 Inhibition of secreted frizzled-related protein 5 improves glucose metabolism. American Journal of Physiology: Endocrinology and Metabolism 307 1144-1152. (doi:10.1152/ ajpendo.00283.2014)

Salpeter SJ, Klochendler A, Weinberg-Corem N, Porat S, Granot Z, Shapiro AM, Magnuson MA, Eden A, Grimsby J, Glaser B, et al. 2011 Glucose regulates cyclin D2 expression in quiescent and replicating pancreatic beta-cells through glycolysis and calcium channels. Endocrinology 152 2589-2598. (doi:10.1210/en.2010-1372) 
Terauchi Y, Takamoto I, Kubota N, Matsui J, Suzuki R, Komeda K, Hara A, Toyoda Y, Miwa I, Aizawa S et al. 2007 Glucokinase and IRS-2 are required for compensatory beta cell hyperplasia in response to high-fat diet-induced insulin resistance. Journal of Clinical Investigation 117 246-257. (doi:10.1172/JCI17645)

Teta M, Rankin MM, Long SY, Stein GM \& Kushner JA 2007 Growth and regeneration of adult beta cells does not involve specialized progenitors. Developmental Cell 12 817-826. (doi:10.1016/j.devcel.2007.04.011)

Vasavada RC, Wang L, Fujinaka Y, Takane KK, Rosa TC, Mellado-Gil JM, Friedman PA \& Garcia-Ocana A 2007 Protein kinase C-zeta activation markedly enhances beta-cell proliferation: an essential role in growth factor mediated beta-cell mitogenesis. Diabetes 56 2732-2743. (doi:10.2337/db07-0461)

Weir GC \& Bonner-Weir S 2007 A dominant role for glucose in beta cell compensation of insulin resistance. Journal of Clinical Investigation 117 81-83. (doi:10.1172/JCI30862)

Zhang H, Li W, Wang Q, Wang X, Li F, Zhang C, Wu L, Long H, Liu Y, Li X, et al. 2012 Glucose-mediated repression of menin promotes pancreatic beta-cell proliferation. Endocrinology 153 602-611. (doi:10.1210/en.2011-1460)

Received in final form 7 February 2016

Accepted 11 February 2016

Accepted Preprint published online 11 February 2016
(C) 2016 Society for Endocrinology Printed in Great Britain
Published by Bioscientifica Ltd. 